\title{
Responses of Winter Wheat to Herbicide-Fungicide Tankmixes
}

\author{
Soltani Nader*, Christy Shropshire, Peter H. Sikkema \\ University of Guelph Ridgetown Campus, Ridgetown, Canada \\ Email: "soltanin@uoguelph.ca
}

Received 15 October 2015; accepted 20 November 2015; published 23 November 2015

Copyright (C) 2015 by authors and Scientific Research Publishing Inc.

This work is licensed under the Creative Commons Attribution International License (CC BY). http://creativecommons.org/licenses/by/4.0/

(c) (i) Open Access

\section{Abstract}

Tankmixing herbicides with fungicides could improve production efficiency and reduce application costs. A total of six field trials were conducted from 2012 to 2014 in Ontario to study the tolerance of winter wheat to herbicide (fenoxaprop-p-ethyl/mefenpyr, prosulfuron + bromoxynil and fluroxypyr + MCPA ester) plus fungicide tankmixes (pyraclostrobin/metconazole, trifloxystrobin/propiconazole, azoxystrobin/propiconazole and picoxystrobin) applied alone and as a tankmix. At 1 WAT, fenoxaprop-p-ethyl/mefenpyr applied alone or in tankmix with trifloxystrobin/propiconazole or azoxystrobin/propiconazole fungicides caused minimal visible injury (up to $1.3 \%$ ) in winter wheat but caused no significant injury when applied as a tankmix with pyraclostrobin/metconazole or picoxystrobin fungicides. There was no effect on visible injury in winter wheat with other herbicide and fungicide tankmixes. Fenoxaprop-p-ethyl/mefenpyr applied alone with no fungicide reduced winter wheat height $3 \%$ but had no adverse effect on height when tankmixed with fungicides evaluated. Prosulfuron + bromoxynil or fluroxypyr + MCPA ester herbicides applied alone with no fungicide or tankmixed with pyraclostrobin/metconazole, trifloxystrobin/propiconazole, azoxystrobin/propiconazole and picoxystrobin fungicides had no adverse effect on winter wheat height. There was no adverse effect of herbicide plus fungicide treatments on winter wheat yield. Co-application of fenoxaprop-p-ethyl/mefenpyr, prosulfuron + bromoxynil and fluroxypyr + MCPA ester herbicides with pyraclostrobin/metconazole, trifloxystrobin/propiconazole, azoxystrobin/propiconazole and picoxystrobin fungicides could provide winter wheat growers with a single-pass treatment for the control of weeds and diseases.

\section{Keywords}

Fenoxaprop-p-ethyl/mefenpyr, Prosulfuron + Bromoxynil, Fluroxypyr + MCPA Ester, Pyraclostrobin/Metconazole, Trifloxystrobin/Propiconazole, Azoxystrobin/Propiconazole, Picoxystrobin

\footnotetext{
${ }^{*}$ Corresponding author.
} 


\section{Introduction}

Winter wheat (Triticum aestevum L.) is a major cereal crops in Canada grown on over 700,000 hectares [1]. In recent years, winter wheat production has increased in Ontario because of new, improved cultivars with higher yields and increased prices for wheat [2]. Winter wheat production is popular among growers as it can be grown in various soil types and is an ideal crop to include in the crop rotation as it helps to improve soil structure and breaks weed and disease life cycles [3]. Intensive agronomic practices, including effective integrated crop management strategies are needed for profitable production of this crop.

Weed control and disease management are among the most important management considerations in winter wheat production. For weed management, growers often use postemergence (POST) application of fenoxapropp-ethyl/mefenpyr, prosulfuron + bromoxynil and fluroxypyr + MCPA ester herbicides to control problem weeds in winter wheat [4]. For disease management, growers often use single or multiple POST application of fungicides such as pyraclostrobin/metconazole, trifloxystrobin/propiconazole, azoxystrobin/propiconazole or picoxystrobin. Although optimum application timing of these POST herbicides and fungicides often coincides, currently, no combination of herbicides and fungicides is labeled for use in winter wheat grown in Ontario. Co-application of POST herbicides with fungicides can allow growers to reduce the number of passes through the field and reduce fuel and labor costs, wear and tear on machinery, soil compaction, as well as mechanical damage to the crop [5]-[7].

There are no published data on the effects of winter wheat to the co-application of fenoxaprop-p-ethyl/ mefenpyr, prosulfuron + bromoxynil and fluroxypyr + MCPA ester herbicides with pyraclostrobin/metconazole, trifloxystrobin/propiconazole, azoxystrobin/propiconazole and picoxystrobin fungicides under Ontario environmental conditions. In addition, information on compatibility of these herbicides with fungicides is very important to winter wheat growers as incompatibility in the tank can result in significant crop and equipment damage as well as reduction in weed and other pest control [6]. More research is needed to identify herbicides and fungicides tankmixes that provide consistent control of problem weeds and diseases while providing adequate margin of crop safety in winter wheat. Co-application of fenoxaprop-p-ethyl/mefenpyr, prosulfuron + bromoxynil and fluroxypyr + MCPA ester herbicides with pyraclostrobin/metconazole, trifloxystrobin/propiconazole, azoxystrobin/propiconazole and picoxystrobin fungicides can provide winter wheat growers with a single-pass treatment for the control of troublesome weeds and diseases.

The objective of this research is to determine if the addition of pyraclostrobin/metconazole, trifloxystrobin/ propiconazole, azoxystrobin/propiconazole and picoxystrobin fungicides to fenoxaprop-p-ethyl/mefenpyr, prosulfuron + bromoxynil and fluroxypyr + MCPA ester herbicides increases crop injury in winter wheat.

\section{Materials and Methods}

Six field studies were conducted at the Ridgetown Campus of the University of Guelph, Ridgetown, Ontario in 2012, 2013 and 2014 (two trials each year). Field experiments were established as a 2-way factorial in a complete randomized block design with four replications. Factor one was herbicide treatments which included fe-

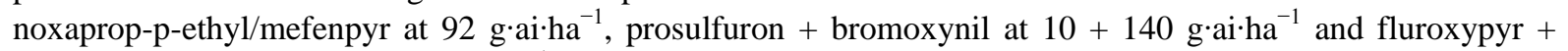
MCPA ester at $108+560 \mathrm{~g} \cdot \mathrm{ai} \cdot \mathrm{ha}^{-1}$ and factor 2 was fungicide treatments which included pyraclostrobin/metconazole at $105 \mathrm{~g} \cdot \mathrm{ai} \cdot \mathrm{ha}^{-1}$, trifloxystrobin/propiconazole at $125 \mathrm{~g} \cdot \mathrm{ai} \cdot \mathrm{ha}^{-1}$, azoxystrobin/propiconazole at $200 \mathrm{~g} \cdot \mathrm{ai} \cdot \mathrm{ha}^{-1}$ and picoxystrobin at $125 \mathrm{~g} \cdot \mathrm{ai} \cdot \mathrm{ha}^{-1}$ (Table 1 ). A non-treated check was included for comparison.

Plots were $2 \mathrm{~m}$ wide and $8 \mathrm{~m}$ long. Pioneer "25R47”, a commonly grown soft, red winter wheat cultivar in Ontario, was seeded in rows spaced $18 \mathrm{~cm}$ apart. At all locations, winter wheat was seeded $3 \mathrm{~cm}$ deep at a rate of $150 \mathrm{~kg} \cdot \mathrm{ha}^{-1}$ using a double disk planter in late September to late October.

Treatments were applied POST in the spring when winter was $20 \mathrm{~cm}$ in height with a $\mathrm{CO}_{2-}$ pressurized back-pack sprayer equipped with Hypro ULD120 - 02 nozzle tips (Hypro, New Brighton, MN) calibrated to deliver $200 \mathrm{~L} \cdot \mathrm{ha}^{-1}$ of water at $200 \mathrm{KPA}$. Herbicide applications were made with a $1.5 \mathrm{~m}$ boom with four nozzles spaced $50 \mathrm{~cm}$ apart.

Estimate of crop injury were evaluated on a scale of $0 \%$ to $100 \%$ at $1,2,4$ and 8 weeks after treatment (WAT). A rating of 0 was defined as no visible injury and a rating of 100 was defined as total crop necrosis. Winter wheat height was measured at 8 WAT within each plot. Yield was measured at crop maturity by harvesting the middle $1.5 \mathrm{~m}$ of each plot with a plot combine. Winter wheat was harvested in late July to early 
Table 1. Main effects and interaction for percent visible injury, height, and yield of winter wheat treated with various herbicide and fungicide tankmixes. Means followed by the same letter within a column are not significantly different according to Fisher's Protected LSD at $P<0.05$. Means for a main effect were separated only if there was no significant interaction involving that main effect ${ }^{\mathrm{a}}$.

\begin{tabular}{|c|c|c|c|c|c|}
\hline \multirow{2}{*}{ Main effects ${ }^{1}$} & \multirow{2}{*}{ Rate (g·ai ha ${ }^{-1}$ ) } & \multicolumn{2}{|c|}{ Wheat injury } & \multirow{2}{*}{ Height } & \multirow{2}{*}{ Yield } \\
\hline & & $1 \mathrm{WAT}$ & 2 WAT & & \\
\hline & & \multicolumn{2}{|c|}{ \% } & $\mathrm{cm}$ & MT.ha ${ }^{-1}$ \\
\hline Herbicide treatment & & ** & ** & NS & NS \\
\hline Untreated check & & 0.0 & $0.0 \mathrm{a}$ & 71.6 & 5.89 \\
\hline No herbicide & & 0.0 & $0.0 \mathrm{a}$ & 71.3 & 5.82 \\
\hline Fenoxaprop-p-ethyl/mefenpyr & 92 & 0.9 & $0.8 \mathrm{~b}$ & 71.8 & 5.94 \\
\hline Prosulfuron + bromoxynil & $10+140$ & 0.2 & $0.1 \mathrm{a}$ & 72.4 & 5.74 \\
\hline Fluroxypyr + MCPA ester & $108+560$ & 0.1 & $0.0 \mathrm{a}$ & 72.5 & 5.65 \\
\hline Fungicide treatment & & NS & NS & ** & NS \\
\hline Untreated check & & 0.0 & 0.0 & 71.6 & 5.89 \\
\hline No fungicide & & 0.2 & 0.2 & 71.5 & 5.79 \\
\hline Pyraclostrobin/metconazole & 105 & 0.2 & 0.1 & 72.3 & 5.86 \\
\hline Trifloxystrobin/propiconazole & 125 & 0.2 & 0.1 & 72.4 & 5.79 \\
\hline Azoxystrobin/propiconazole & 200 & 0.3 & 0.2 & 72.0 & 5.73 \\
\hline Picoxystrobin & 125 & 0.2 & 0.1 & 71.8 & 5.77 \\
\hline \multicolumn{6}{|l|}{ Interaction } \\
\hline $\mathrm{H} \times \mathrm{F}$ & & * & NS & * & NS \\
\hline
\end{tabular}

${ }^{\mathrm{a}}$ Abbreviations: $\mathrm{F}$, fungicide treatment; $\mathrm{H}$, herbicide treatment; NS, not significant at $P=0.05$ level; WAT, weeks after treatment. ${ }^{\mathrm{b}}$ Significance at $P<$ 0.05 and $P<0.01$ levels denoted by ${ }^{*}$ and ${ }^{* *}$, respectively. Non-treated check was included for comparison among herbicide and fungicide treatments.

august in each year. Yields were adjusted to $14.5 \%$ moisture.

Data were analyzed as a 2-way factorial using PROC MIXED in SAS 9.2 [8]. Fixed effects included the two treatment factors, herbicide treatment and fungicide treatment, as well as their interaction; random effects included year-location combinations (environment), interactions between environment and the fixed effects, and replicate nested within environment. Significance of fixed effects were tested using F-tests and random effects were tested using a Z-test of the variance estimate. The UNIVARIATE procedure was used to test data for normality and homogeneity of variance. To satisfy the assumptions of the variance analyses, injury 1 and 2 WAT were arcsine square root transformed. For all injury ratings, the untreated check (assigned a value of zero) was excluded from the analysis. However, all values were compared independently to zero to evaluate treatment differences with the untreated check. Treatment comparisons were made using Fisher's Protected LSD at a level of $P<0.05$ and any data compared on the transformed scale were converted back to the original scale for presentation of results.

\section{Results and Discussion}

Data were pooled and averaged over environments when there were no statistical interactions (Tables 1-3). There were no visible incompatibility problems in respect to the spray solution or application with the various herbicide plus fungicide tankmixes evaluated in this study (data not shown). Visible injury at 4 and 8 WAT were all zero and therefore are not shown.

\subsection{Visible Injury}

There was slightly higher visible injury with fenoxaprop-p-ethyl/mefenpyr compared to prosulfuron + bromoxynil or fluroxypyr + MCPA ester herbicides when applied alone in winter wheat 2 WAT (Table 1). There was 
no visible injury in winter wheat when pyraclostrobin/metconazole, trifloxystrobin/propiconazole, azoxystrobin/propiconazole and picoxystrobin fungicides were applied alone 1 or 2 WAT (Table 1). However, there was a significant herbicide by fungicide treatment interaction for winter wheat injury at 1 WAT (Table 1). Fenoxaprop-p-ethyl/mefenpyr applied alone or in tankmix with trifloxystrobin/propiconazole or azoxystrobin/pro- picona-zole fungicides caused slightly higher visible injury in winter wheat than when applied as a tankmix with pyraclostrobin/metconazole or picoxystrobin fungicides (Table 2). There was no effect on visible injury in winter wheat with other herbicide and fungicide tankmixes at 1 WAT (Table 2). Results are similar to other studies [9] that have shown less than $2.5 \%$ injury with co-application of pyraclostrobin, azoxystrobin, propiconazole, azoxystrobin/propiconazole, tebuconazole or trifloxystrobin/propiconazole with herbicides such as glyphosate in soybean at 1 WAT.

\subsection{Plant Height}

There was a significant herbicide by fungicide treatment interaction for winter wheat height (Table 1). Fenoxaprop-p-ethyl/mefenpyr applied alone with no fungicide reduced winter wheat height $3 \%$ but had no adverse effect on winter wheat height when tankmixed with pyraclostrobin/metconazole, trifloxystrobin/propiconazole, azoxystrobin/propiconazole and picoxystrobin fungicides (Table 3). Prosulfuron + bromoxynil or fluroxypyr + MCPA ester herbicides applied alone with no fungicide or tankmixed with pyraclostrobin/metconazole, trifloxystrobin/propiconazole, azoxystrobin/propiconazole and picoxystrobin fungicides had no adverse effect on winter wheat height (Table 3). In other studies, Grichar and Prostko [9] found no or minimal (3\%) stunting in soybean with glyphosate tankmixed with fungicides such as azoxystrobin, tebuconazole, pyraclostrobin and tetraconazole. Other studies have also shown that the addition of azoxystrobin, propiconazole, azoxystrobin/propiconazole, tebuconazole and trifloxystrobin/propiconazole to herbicides such as glyphosate causes no adverse effects on soybean height [10].

Table 2. Percent visible injury 1 WAT for winter wheat treated with various herbicide and fungicide tankmixes. Means followed by the same letter within a column (a-b) or row (Y-Z) are not significantly different according to Fisher's Protected LSD at $P<0.05^{\mathrm{a}}$.

\begin{tabular}{cccccc}
\hline \multirow{2}{*}{ Herbicide treatment } & \multicolumn{5}{c}{ Wheat injury } \\
\cline { 2 - 6 } & $\begin{array}{c}\text { No } \\
\text { fungicide }\end{array}$ & $\begin{array}{c}\text { Pyraclostrobin/ } \\
\text { metconazole }\end{array}$ & $\begin{array}{c}\text { Trifloxystrobin/ } \\
\text { propiconazole }\end{array}$ & $\begin{array}{c}\text { Azoxystrobin/ } \\
\text { propiconazole }\end{array}$ & Picoxystrobin \\
\cline { 4 - 6 } No herbicide & $0.0 \mathrm{a}$ & $0.0 \mathrm{a}$ & $0.0 \mathrm{a}$ & $0.0 \mathrm{a}$ & $0.1 \mathrm{a}$ \\
Fenoxaprop-p-ethyl/mefenpyr & $1.1 \mathrm{~b} \mathrm{Y}$ & $0.6 \mathrm{~b} \mathrm{Z}$ & $1.3 \mathrm{~b} \mathrm{Y}$ & $1.1 \mathrm{~b} \mathrm{Y}$ & $0.5 \mathrm{~b} \mathrm{Z}$ \\
Prosulfuron + bromoxynil & $0.1 \mathrm{a}$ & $0.3 \mathrm{~b}$ & $0.1 \mathrm{a}$ & $0.2 \mathrm{ab}$ & $0.1 \mathrm{a}$ \\
Fluroxypyr + MCPA ester & $0.1 \mathrm{a}$ & $0.1 \mathrm{ab}$ & $0.0 \mathrm{a}$ & $0.2 \mathrm{a}$ & \\
\hline
\end{tabular}

${ }^{\mathrm{a}}$ Abbreviations: WAT, weeks after treatment.

Table 3. Height 8 WAT for winter wheat treated with various herbicide and fungicide tankmixes. Means followed by the same letter within a column (a-b) or row (Y-Z) are not significantly different according to Fisher's Protected LSD at $P<$ $0.05^{\mathrm{a}}$.

\begin{tabular}{|c|c|c|c|c|c|}
\hline \multirow[b]{2}{*}{ Herbicide treatment } & \multicolumn{5}{|c|}{ Wheat height } \\
\hline & $\begin{array}{c}\text { No } \\
\text { fungicide }\end{array}$ & $\begin{array}{l}\text { Pyraclostrobin/ } \\
\text { metconazole }\end{array}$ & $\begin{array}{l}\text { Trifloxystrobin/ } \\
\text { propiconazole }\end{array}$ & $\begin{array}{l}\text { Azoxystrobin/ } \\
\text { propiconazole }\end{array}$ & Picoxystrobin \\
\hline & & & $\mathrm{cm}$ & - & \\
\hline No herbicide & $71.6 \mathrm{~b}$ & $71.1 \mathrm{a}$ & $71.6 \mathrm{a}$ & $70.6 \mathrm{a}$ & $71.2 \mathrm{a}$ \\
\hline Fenoxaprop-p-ethyl/mefenpyr & 69.6 a Z & 72.5 ab Y & 72.6 a Y & $72.5 \mathrm{~b} \mathrm{Y}$ & 71.7 a Y \\
\hline Prosulfuron + bromoxynil & 71.8 b Z & $73.2 \mathrm{~b} \mathrm{Y}$ & 72.6 a YZ & $72.2 \mathrm{ab} Y Z$ & 72.3 a YZ \\
\hline Fluroxypyr + MCPA ester & $72.9 \mathrm{~b}$ & $72.4 \mathrm{ab}$ & $72.8 \mathrm{a}$ & $72.6 \mathrm{~b}$ & $71.9 \mathrm{a}$ \\
\hline
\end{tabular}

${ }^{\mathrm{a}}$ Abbreviations: WAT, weeks after treatment. 


\subsection{Yield}

Seed moisture content ranged from $15.9 \%$ to $16.2 \%$ and was not significantly different with any herbicide, fungicide or their tankmix (data not shown). There was not a significant herbicide by fungicide treatment interaction for winter wheat yield (Table 1). There was no adverse effect of fenoxaprop-p-ethyl/mefenpyr, prosulfuron + bromoxynil and fluroxypyr + MCPA ester herbicides and pyraclostrobin/metconazole, trifloxystrobin/propiconazole, azoxystrobin/propiconazole and picoxystrobin fungicides applied alone or as a tankmix in winter wheat (Table 1). This is similar to other studies that have shown that the co-application of pyraclostrobin, azoxystrobin, propiconazole, azoxystrobin/propiconazole, tebuconazole or trifloxystrobin/propiconazole fungicides with herbicides such as glyphosate has no adverse effect on soybean yield [10].

\section{Conclusion}

Overall, fenoxaprop-p-ethyl/mefenpyr, prosulfuron + bromoxynil and fluroxypyr + MCPA ester herbicides and pyraclostrobin/metconazole, trifloxystrobin/propiconazole, azoxystrobin/propiconazole and picoxystrobin applied alone and, as a tankmix in winter wheat, caused minimal injury and plant height reduction and had no adverse effect on the yield of winter wheat. Based on these results, herbicides and fungicides at rates evaluated could be tankmixed if co-application of herbicides and a fungicide was desired. The combination of fenoxaprop-p-ethyl/ mefenpyr, prosulfuron + bromoxynil and fluroxypyr + MCPA ester herbicides with pyraclostrobin/metconazole, trifloxystrobin/propiconazole, azoxystrobin/propiconazole or picoxystrobin fungicides could provide winter wheat growers with an integrated option that would increase the spectrum of pest control and crop production efficiency.

\section{Acknowledgements}

The authors would like to acknowledge Lynette Brown and Holly Byker for their expertise and technical assistance in these studies. Funding for this project was provided in part by the Grain Farmers of Ontario and the GF2 program of the Agricultural Adaptation Council.

\section{References}

[1] Agriculture and Agri-Food Canada (2010) Crop Profile for Winter Wheat in Canada. Pesticide Risk Reduction Program, Pest Management Center, Ottawa. http://publications.gc.ca/collections/collection-2012/agr/A118-10-29-2012-eng.pdf

[2] Swanton, C.J. (2004) Ontario Field Crops Research and Services Committee Annual Report. Ontario Ministry of Agriculture and Food, Toronto, 26.

[3] Alberta Wheat Commission (2013) Winter Wheat Production Manual. Alberta Wheat Commission, Calgary. http://www.growwinterwheat.ca/documents/winter-wheat-production-manual.pdf

[4] Ontario Ministry of Agriculture, Food, and Rural Affairs (OMAFRA) (2014) Guide to Weed Control. Publication 75, Ontario Ministry of Agriculture, Food, and Rural Affairs, Toronto.

[5] Jordan, D.L., Culpepper, A.S., Grichar, W.J., Tredaway-Ducar, J., Brecke, B.J. and York, A.C. (2003) Weed Control with Combinations of Selected Fungicides and Herbicides Applied Postemergence to Peanut (Arachis hypogaea L.). Peanut Science, 30, 1-8. http://dx.doi.org/10.3146/pnut.30.1.0001

[6] Lancaster, S.H., Jordan, D.L., Brandenburg, R.L., Royal, B., Shew, B., Bailey, J., Curtis, V., York, A.C., Wilcut, J.W., Beam, J., Prostko, E., Culpepper, A.S., Grey, T., Johnson III, C., Kemerait, R., Brecke, B., McDonald, G., Tredaway-Ducar, J., College, B. and Wall, B. (2005) Tank Mixing Chemicals Applied to Peanut Crops: Are the Chemicals Compatible? Extension Bulletin No. AGW653, North Carolina Cooperative Extension Service, NC, 11 p.

[7] Lancaster, S.H., Jordan, D.L., Spears, J.F., York, A.C., Wilcut, J.W., Monks, D.W., Batts, R.B. and Brandenburg, R.L. (2005) Sicklepod (Senna obtusifolia) Control and Seed Production after 2, 4-DB Applied Alone and with Fungicides or Insecticides. Weed Technology, 19, 451-455. http://dx.doi.org/10.1614/WT-04-227R

[8] Statistical Analysis Systems (SAS) (2008) The SAS System for Windows, Release 9.2. Statistical Analysis Systems Institute, Cary.

[9] Grichar, J.W. and Prostko, E.P. (2009) Effect of Glyphosate and Fungicide Combinations on Weed Control in Soybeans. Crop Protection, 28, 619-622. http://dx.doi.org/10.1016/j.cropro.2009.03.006

[10] Soltani, N., Shropshire, C. and Sikkema, P.H. (2012) Co-Application of Glyphosate Plus an Insecticide or Fungicide in Glyphosate-Resistant Soybean. Canadian Journal of Plant Science, 92, 297-302.

http://dx.doi.org/10.4141/cjps2011-166 